\title{
MADAME WERTEN — ARTYSTKA I PROPAGATORKA SZTUKI. TROPY Z MUZEUM POLSKIEGO W AMERYCE
}

Asystentem samej Marii Skłodowskiej-Curie w Paryżu był wybitny profesor fizyki Ludwik Wertenstein $^{1}$, brat Marii ${ }^{2}$ Werten vel Wertenstein (urodzonej 22 września 1888 w Warszawie a zmarłej 4 grudnia 1949 w Los Angeles) ${ }^{3}$, artystki, która studiowała W stolicy Francji ${ }^{4}$. Niestety nic więcej nie wiadomo o tym okresie jej życia. Madame Werten nazywana była w Kalifornii, gdzie szkoliła rysowników Walt Disney Studios. Ocalał nawet dziesięciominutowy film instruktażowy dla nauczycieli sztuk plastycznych — wyprodukowany w 1940 roku w USA — z udziałem Marii Werten, który znajduje się w Steven Spielberg Film and Video Archive w Waszyngtonie ${ }^{5}$. Intrygująca

${ }^{1}$ Ludwik Wertenstein (1887-1945), polski fizyk, pionier fizyki jądrowej w Polsce.

${ }^{2}$ W USA stosowała pisownię imienia Marya.

${ }^{3}$ Dane pochodzą z aktu zgonu wydanego w Kalifornii i zostały potwierdzone w dalszych badaniach. Nie zachował się akt urodzenia. W literaturze przedmiotu często pojawiały się błędne daty urodzenia i śmierci Marii Werten.

${ }^{4}$ F. Bolek, Who's Who in Polish America, New York 1970, s. 486.

${ }^{5}$ Zdjęcia nakręcone w latach 30. XX wieku w Polsce przez Amerykankę Eleanor J. Danner, ukazują mieszkańców wsi różnych regionów kraju, ich odświętne stroje oraz wyroby artystyczne przez nich wytwarzane. Miał to być film instruktażowy dla nauczycieli sztuk plastycznych ceniących sztukę ludową. Na filmie zatytułowanym Folkways of Poland: Costumes, Crafts, Dances pojawia się Maria Werten oraz jej profesor, grafik Edmund Bartłomiejczyk, na koniec ukazane są widoki Warszawy. Film wyprodukowany został w 1940 roku w USA na zlecenie Międzynarodowej Szkoły Sztuki, w której działała Maria Werten, propagując sztukę polską. 
malarka, rysowniczka, graficzka, projektantka, $\operatorname{pedagog}^{6}$ i propagatorka sztuki polskiej za granicą za swoje zasługi została odznaczona pośmiertnie przez Augusta Zaleskiego, prezydenta Rzeczypospolitej Polskiej na uchodźstwie w 1950 roku. List w tej sprawie znajduje się w MPA, przechowującym spuściznę artystki, w tym największy zbiór jej prac, prawie 400 obiektów. Oto rezultaty fascynujących, amerykańskich i polskich poszukiwań tropem Marii Werten, przyczynek do dalszej kwerendy, także we Francji.

W artykule wybitnego krytyka teatralnego, literata i jednocześnie siostrzeńca artystki, Jana Kotta widnieje następujący podpis pod reprodukcją: „Jedyny zachowany obraz Marii Werten, portret ${ }^{7}$ pięcioletniej Anielki (Lalutki) Kott" ${ }^{8}$. Bogata chicagowska kolekcja - przekazana z Nowego Jorku w 1945 roku przez Irenę Piotrowską, za przyzwoleniem Marii Werten — była tak długo nieznana. Donacja nosi w Archiwum MPA sygnaturę darowizny nr 18 i obejmuje szczegółowe spisy ofiarowanych dzieł sztuki, rękopisy listów Marii Werten, Ireny Piotrowskiej i Mieczysława Haimana, kustosza MPA. Są tu nawet klucze do skrzyń, w których transportowano spuściznę artystki.

Składa się na nią blisko 90 prac sygnowanych przez Werten oraz niepodpisanych i opieczętowanych stemplem Międzynarodowej Szkoły Sztuki, z których — jak się wydaje — nie wszystkie są jej autorstwa. [...] Natomiast niemal połowę stanowią akwarele i pastele ukazujące dzieci podczas pracy, w zabawie, przy modlitwie, a także na portretach (czasami w strojach ludowych). Drugą liczną część stanowi grafika użytkowa: ilustracje ${ }^{9}$, różne wzory ozdobnego papieru do pakowania, karty świąteczne i okolicznościowe, plakaty, w tym reklamujące Międzynarodową Szkołę Sztuki oraz Fabrykę Zabawek Gnom ${ }^{10}$, a także zabawki drewniane w tejże fabryce, przypuszczalnie wykonane według projektu Marii Werten $^{11}$. Ostatnią grupę stanowią trzy projekty tapet ${ }^{12}$.

Po przeprowadzeniu - po raz pierwszy w historii placówki - inwentaryzacji prac Marii Werten w MPA w 2010 roku $^{13}$, należy zweryfikować nieco opis z przewodnika Muzeum Polskiego w Ameryce wydanego w 2003 roku. Zbiór grafiki użytkowej liczy

${ }^{6}$ Podczas inwentaryzacji prac graficznych w Muzeum Polskim w Ameryce (dalej: MPA) należących do spuścizny Marii Werten odnaleziono między innymi aż 96 niewielkich linorytów i drzeworytów z okresu międzywojennego wykonanych przez dzieci, jej uczniów. Prace zwracają uwagę wysokim poziomem artystycznym; zob.: M. Nowak, Maria Werten and the Work of Her Young Students, The Polish Museum of America Newsletter 2009 nr 2, s. 16.

${ }^{7}$ Obecnie portret siostry Jana Kotta znajduje się w USA, gdzie mieszka jego córka Teresa Berger, właścicielka obrazu.

${ }^{8}$ J. Kott, Maria Wertenstein do Kazimiery Kott. Listy z lat 1946-1949, Archiwum Emigracji. Studia - Szkice - Dokumenty, 2000 nr 3, s. 131.

${ }^{9}$ Maria Werten była ilustratorką wielu książek dla dzieci, wydanych w Polsce i Stanach Zjednoczonych.

${ }^{10}$ Pełna nazwa fabryki działającej w Warszawie: Zakład Przemysłu Zabawkarskiego, Instrumentów Muzycznych i Drobnych Wyrobów Drzewnych „Gnom”.

${ }^{11}$ Maria Werten współpracowała także z Warsztatami Krakowskimi.

${ }^{12}$ Muzeum Polskie w Ameryce. Dzieje i zbiory. Przewodnik, M. Kot [i in.], Warszawa 2003, s. 182-184.

${ }^{13}$ M. Nowak, ,Spis inwentaryzacyjny prac Marii Werten przechowywanych w chicagowskim Muzeum Polskim w Ameryce", Chicago 2010 (maszynopis w archiwum autorki). 
bowiem blisko 200 prac. Uzupełnić tę listę też trzeba o ponad 20 przykładów grafiki warsztatowej, w tym pięć litografii zatytułowanych Dziecko lub Dziewczyna i ptak (pod tym drugim tytułem oferował grafikę jeden z polskich domów antykwarycznych) oraz 15 różnych wariantów kolorystycznych litografii Kobieta niosąca wodę, gdzie w kilku przypadkach są one sygnowane ręcznie ołówkiem przez artystkę. Zdarza się, że na rewersie prac istnieją inne próbki odbitek tejże grafiki.

Kolekcja zachowana w MPA pokazuje, że stylistyka twórczości Marii Werten ewoluowała od secesji ku art deco ${ }^{14}$. Artystka studiowała w Szkole Sztuk Pięknych w Warszawie. Uczestniczyła w wielu wystawach Towarzystwa Zachęty Sztuk Pięknych. W MPA są dwie prace z wystawy, która odbyła się w gmachu warszawskiej Zachęty w 1916 roku. Werten została nagrodzona listem pochwalnym za dzieło nadesłane na konkurs malarski i graficzny im. Marii Klass-Kazanowskiej w 1919 roku ${ }^{15}$. Poza dominującymi tematami prac jak dzieci, sceny religijne związane z tradycją bożonarodzeniową, portrety, pojawiają się w twórczości Marii Werten również wątki zaczerpnięte $\mathrm{z}$ natury — stylizowane motywy roślinne, ptaki. Jeden z krytyków okresu międzywojennego napisał, że:

Maria Werten wykreowała [...] dosyć specyficzny światek malarsko-poetycki

złożony z dziecięcych fantazji, kobiecej uczciwości, dyskretnych reminiscencji

Mehoffera, Wyspańskiego, Wojtkiewicza, Vlastimila Hofmana ${ }^{16}$.

Jak podkreślano w przewodniku muzealnym z 2003 roku:

Słowa te bardzo trafnie oddają charakter jej malarstwa, ale nie obejmują grafiki użytkowej, w której postacie i przedstawienia są silnie stylizowane, [...], zgeometryzowane $[\ldots]^{17}$.

Maria Werten pochodziła z zasymilowanej, świetnie wykształconej rodziny żydowskiej należącej do ówczesnej elity w Polsce. Jej ojciec był lekarzem. Mieszkali w Warszawie - w domu rodziców - na prestiżowej ulicy Senatorskiej pod numerem szóstym (w MPA zachował się telegram z tym adresem). Była spokrewniona $\mathrm{z}$ wieloma utalentowanymi ludźmi. Wertensteinowie powiązani byli z rodem Toeplitzów i Żuławskich oraz z Leonem Chwistkiem, a także słynnym matematykiem, profesorem Hugonem Steinhausem. Poza wspomnianymi, bratem Ludwikiem Wertensteinem i siostrzeńcem Janem Kottem, który traktował Marię Werten jak matkę ${ }^{18}$, miała siostrę biologa, a córka brata, Wanda Wertenstein, była znanym krytykiem filmowym, bohaterką opowiadania Jerzego Andrzejewskiego i filmu Andrzeja Wajdy pod tytułem Wielki tydzień. Wertensteinowie często bywali w domu Jarosława Iwaszkiewicza na Stawisku, tam odnajdując chwile wytchnienia podczas drugiej wojny światowej ${ }^{19}$.

${ }^{14}$ Taż, Madame Werten, Polish American Studies 2010 nr 1, s. 77-79.

${ }^{15}$ Dokumenty dotyczące Marii Werten oraz katalogi Zachęty z jej pracami dostępne są w warszawskich bibliotekach i archiwach, między innymi Akademii Sztuk Pięknych, Instytutu Sztuki PAN, Zachęty.

${ }^{16}$ Sztuki Plastyczne, Pro Arte 1919 z. 3, s. 23; cyt. za: Muzeum Polskie w Ameryce, s. 182.

${ }^{17}$ Muzeum Polskie w Ameryce, s. 182.

18 J. Kott, Still Alive. An Autobiographical Essay, New Haven-London 1994, s. 144.

${ }^{19}$ J. Iwaszkiewicz, Dzienniki, Warszawa 2007, s. 221. 
We wrześniu 2009 roku spotkałam się ze Zbigniewem Mańkowskim, który posiada obraz Marii Werten w swoim warszawskim mieszkaniu ${ }^{20}$. Jest to jedyne dzieło sztuki $\mathrm{z}$ bogatej kolekcji należącej do rodziny, które przetrwało powstanie warszawskie. Ojcem Zbigniewa Mańkowskiego był Bronisław Mańkowski, właściciel wspomnianej Fabryki Zabawek „Gnom”, z którym Maria Werten współpracowała jako projektantka. Była przez niego bardzo lubiana i ceniona, toteż po wybuchu wojny pragnął jej pomóc, ale — mimo poszukiwań — nie mógł jej odnaleźć. Dla bezpieczeństwa rodzina ukrywała fakt, że Maria Werten w 1939 roku była już w Nowym Jorku. W latach 30. XX wieku płynęła z Europy do Ameryki aż sześciokrotnie (1933, 1935, 1936, 1937, 1939). Zachowały się spisy transatlantyckich statków pasażerskich, które to potwierdzają.

Podróże były związane z działalnością artystki, m.in. z popularyzacją sztuki polskiej w Stanach Zjednoczonych. Maria Werten była dyrektorem w organizacji International School of Art (Międzynarodowa Szkoła Sztuki) założonej przez Amerykankę Elmę Pratt z siedzibami w Polsce (Zakopane, Warszawa), Austrii, Czechosłowacji, Rumuni, na Węgrzech, we Włoszech, Tunezji i Stanach Zjednoczonych, a po 1945 roku także w Meksyku. W opublikowanej pracy magisterskiej Nicole Ruth Cardassilaris zatytułowanej Bringing Cultures Together: Elma Pratt, Her International School of Art, and Her Collection of International Folk Art at the Miami University Art Museum (Cincinnati 2008), można szczegółowo poznać zasady działania Międzynarodowej Szkoły Sztuki, której celem była integracja międzykulturowa, poznanie specyfiki sztuki ludowej innych krajów i czerpanie z niej inspiracji. Autorka pracy wymieniła Marię Werten kilkakrotnie w swoim tekście, ale informacje są bardzo lakoniczne. Dodam, że w archiwum Miami University Art Museum w Oksfordzie w stanie Ohio zachowało się zdjęcie z 1928 roku z Zakopanego z uczestnikami Międzynarodowej Szkoły Sztuki, którego nie posiada w swoich zbiorach Muzeum Tatrzańskie. Są na nim nauczyciele plastyki z USA (liczebnie przeważały kobiety), którzy przybyli na letni kurs do Polski, aby poszerzyć wiedzę z pedagogiki i przyjrzeć się lokalnej sztuce ludowej, tak bardzo cenionej przez International School of Art.

Maria Werten często prowadziła wykłady w stanie Ohio (stąd pochodziła Elma Pratt). Na łamach gazety „Cleveland Plain Dealer” z 5 maja 1940 roku nazwano ją nawet „Poland-in-Ohio Lady”. W ramach aktywności szkoły i przy pomocy finansowej Ministerstwa Spraw Zagranicznych Werten wielokrotnie podróżowała do Stanów Zjednoczonych $^{21}$, gdzie prezentowała nie tylko odczyty o sztuce polskiej, ale i publikowała artykuły $^{22}$, prowadziła kursy i organizowała wystawy.

W ciągu pięciu lat (1932-1937) ${ }^{23}$ w 41 największych miastach USA odbyło się z jej udziałem 27 kursów, wygłosiła ponad 200 odczytów połączonych z pokazami, zdobywając uznanie jako nieprzeciętna propagatorka kultury polskiej ${ }^{24}$.

Tu warto zaznaczyć, że za sprawą Marii Werten dociera do Ameryki papieroplastyka ${ }^{25}$. Jej współpracowniczką od roku 1937 była jedna z najbardziej wziętych w Stanach

${ }^{20}$ Do spotkania doszło dzięki Katarzynie Nowakowskiej-Sito, kustoszowi z Muzeum Narodowego w Warszawie.

${ }^{21}$ M. Werten, Wrażenia z Ameryki, Arkady 1935 nr 1, s. 44-45.

${ }^{22}$ Taż, Bartlomiejczyk - Victim of the German War on Polish Art, The Polish Review 1925 nr 3, s. 8-9, 12.

${ }^{23}$ W Muzeum Polskim w Ameryce znajduje się broszura (z ilustracjami Marii Werten) Międzynarodowej Szkoły Sztuki, reklamująca letni kurs prowadzony w Zakopanem przez artystkę od 3 do 17 sierpnia w 1932 roku.

${ }^{24}$ Muzeum Polskie w Ameryce, s. 180. 
Zjednoczonych artystek stosujących dekorację papieroplastyczną — Erika Hanka Górecka Egan, której wystroje witryn sklepowych wzbudziły w USA prawdziwą sensację.

Werten wraz z Marią Lilien-Czarnecką - urodzoną w Zakopanem absolwentką architektury na Politechnice Lwowskiej, a w Stanach Zjednoczonych asystentką Franka Lloyda Wrighta oraz profesorem architektury wnętrz prestiżowego Art Institute w Chicago - przygotowała wystawę polskich drzeworytów ludowych w chicagowskim Instytucie Sztuki w 1943 roku $^{26}$. Natomiast z Ireną Piotrowską ${ }^{27}$, historykiem i krytykiem sztuki, doktorem filozofii Uniwersytetu im. Adama Mickiewicza w Poznaniu, która także studiowała w Paryżu (Ecole du Louvre) oraz była dyrektorem Polish Art Service w Nowym Jorku zorganizowała wielką prezentację sztuki polskiej w Brooklyn Museum of Art w 1933 roku $^{28}$. Plakat reklamujący ekspozycję, zaprojektowany przez mistrza grafiki, Edmunda Bartłomiejczyka, nauczyciela Marii Werten znajduje się w Muzeum Polskim w Ameryce wraz z niektórymi obiektami tam prezentowanymi, na przykład świetnymi przykładami polskiego art deco — plakatami, rzeźbami drewnianymi szkoły zakopiańskiej czy litografiami, akwarelami i rysunkami studentów Szkoły Sztuk Pięknych w Warszawie (od 1932 roku ASP) z lat 20. i 30. XX wieku, między innymi Józefa Puchalskiego, Henryka Jaworskiego i Lucy Brzezińskiej.

W Archiwum MPA przechowywany jest również katalog pokazu ${ }^{29}$ — przygotowanego w grudniu 1939 roku w Muzeum Sztuki w Syracuse — kolekcji obrazów, rzeźb i grafik z Pawilonu Polskiego na Wystawie Światowej w Nowym Jorku 1939-1940. Jego organizacja - przy pomocy Marii Werten wówczas niedawno przybyłej z Europy na wschodnie wybrzeże - była możliwa dzięki zarządzeniu przerwy na zimę w międzynarodowej ekspozycji trwającej do maja 1940 roku. Katalog ma okładkę autorstwa artystki, której wybór prac dołączono wówczas do wystawy.

W kilka lat po zakończeniu Wystawy Światowej Maria Werten przeniosła się do Kalifornii. W 2009 roku $^{30}$, po odnalezieniu listu skierowanego do dyrektora MPA, Jana M. Lorysia wyruszyłam tam jej śladem:

Mam sporo grafik Marii Werten w Kalifornii. Znałam ją. Ona nie tylko dekorowała ściany restauracji „Wilno” w Agoura, której właścicielami byli moi rodzice, ale madame Werten (jak ją nazywaliśmy) czasami się mną opiekowała i używała zdrobnienia mojego imienia Walcia ${ }^{31}$.

Valerie Hunken, mieszkająca w miasteczku Carmel nad Pacyfikiem, posiada wspaniałą kolekcję sztuki polskiej, między innymi portrety rodziców wykonane przez zaprzyjaź-

${ }^{25}$ A. M. Borkowski, O papieroplastyce polskiej, [w:] Sztuka polska w Wielkiej Brytanii 1940-2000. Antologia, red. M. A. Supruniuk, Toruń 2006, s. 47-48.

${ }^{26}$ Sz. Bojko, Z polskim rodowodem. Artyści polscy i amerykańscy polskiego pochodzenia $w$ sztuce Stanów Zjednoczonych w latach 1900-1980, Toruń 2007, s. 352.

${ }^{27}$ A. D. Jaroszyńska-Kirchmann, The Exile Mission: The Polish Political Diaspora and Polish Americans, 1939-1956, Athens 2004, s. 34 (autorka wymienia Marię Werten i Irenę Piotrowską).

${ }^{28}$ To także była wystawa przygotowana z inicjatywy Międzynarodowej Szkoły Sztuki.

${ }^{29}$ Polish Art \& Craft: Modern and Peasant. Painting, Sculptures, Prints from the New York World's Fair, [katalog wystawy], Syracuse Museum of Fine Arts, Syracuse 1939.

${ }^{30}$ M. Nowak, Werten: From Warsaw to California, The Polish Museum of America Newsletter 2010 nr 1, s. 7.

${ }^{31}$ List Valerie Hunken do Jana M. Lorysia z 9 listopada 2007, w archiwum autorki. 
nionego Stanisława Szukalskiego, a także prace owej zapomnianej w ojczyźnie Marii Werten. Valerie Hunken przekazała już wcześniej do Archiwum Muzeum Polskiego w Ameryce arcyciekawą spuściznę ojca, aktora i dziennikarza Leonidasa Dudarewa-Ossetyńskiego, między innymi rękopisy listów Stanisława Szukalskiego i Marii Werten, która w Kalifornii namalowała portret Valerie Hunken, kiedy była ona dzieckiem ${ }^{32}$. Podczas wizyty w Carmel nie tylko udokumentowałam dwa obrazy na desce autorstwa Marii Werten, ale pozyskałam na rzecz MPA nieznane wcześniej grafiki jej autorstwa i — widziane po raz pierwszy — zdjęcia samej artystki i jej dzieł, także z Agoura ${ }^{33}$.

Na prośbę Leonidasa Dudarewa-Ossetyńskiego Maria Werten udekorowała restaurację „Wilno” w Agoura koło Los Angeles, miejsce spotkań polskich weteranów wojennych i artystów. Leonard Siveley tak pamiętał i wspominał Marię Werten z tego okresu:

widziałem ją przy pracy, gdy dekorowała restaurację, była ogromnie sympatyczna, czasem nieco nerwowa, z pasją oddana sztuce, samotna, chociaż towarzyszył jej jakiś mężczyzna, miała wspaniałe poczucie humoru, uczniowie ją uwielbiali $^{34}$.

Restauracja spłonęła wkrótce po otwarciu, jednak cztery obrazy Marii Werten, które udało się uratować przechowywane są obecnie w San Fransisco. Zdjęcia restauracji „Wilno”, na których widać prace Marii Werten, są w posiadaniu Valerie Hunken. Maria Werten pracowała wówczas dorywczo w Chouinard Art Institute w Los Angeles, kształcącej między innymi rysowników dla Walt Disney Studios ${ }^{35}$ oraz udzielała prywatnych lekcji w swoim Norwid Studio. Mimo to żyła w biedzie. Zmarła z powodu powikłań wynikających z przewlekłej astmy ${ }^{36}$ w 1949 roku. Leonidas Dudarew-Ossetyński wygłosił na jej cześć mowę pożegnalną na pogrzebie, którą opublikowa$\mathrm{no}^{37}$. Pochowana została na cmentarzu w Los Angeles, zachowały się zdjęcia $\mathrm{z}$ tej uroczystości.

W nieco symboliczny sposób losy Marii Werten łączą się z Muzeum Polskim w Ameryce przez przypadkową zbieżność roku urodzenia i śmierci, która jest taka sama jak Mieczysława Haimana (1888-1949), pierwszego kustosza Muzeum Polskiego w Ameryce, który ocalił spuściznę Marii Werten w 1945 roku. To on także — w 1941 roku — przyjął obiekty z Pawilonu Polskiego na Wystawie Światowej w Nowym Jorku 1939-1940, stanowiące - obok donacji Marii Werten — trzon kolekcji sztuki z okresu międzywojennego w MPA.

W Chicago powołano w 1935 roku — i uroczyście otwarto w 1937 roku - Muzeum Polskie w Ameryce, dziś jedno z najstarszych i największych muzeów etnicznych w USA. To w stanie Illinois zachowały się dzieła, które są prawdziwą rzadkością

${ }^{32}$ Ta akwarela znalazła się na okładce wydawanego w Nowym Jorku magazynu polonijnego „Biały Orzeł” w styczniu 1948 roku.

${ }^{33} \mathrm{Z}$ albumu rodzinnego Valerie Hunken.

${ }^{34}$ Rozmowa telefoniczna, czerwiec 2009.

35 Szkoła została przekształcona przez Walta Disneya w latach 60. XX wieku w California Institute of the Arts.

${ }^{36}$ Maria Werten podczas pobytu w USA mieszkała też w Denver, lecząc się w klimacie stanu Kolorado.

${ }^{37}$ L. Dudarew-Ossetynski, In Memory of Maria Werten (1888-1949), Biały Orzeł. Polish American Magazine 1950 nr 10, s. 24-26. 
w Polsce, również dlatego, że w niektórych przypadkach dorobek twórcy uległ zniszczeniu w Europie w czasie drugiej wojny światowej.

Prace Marii Werten ze zbiorów MPA wymagają konserwacji i ukryte są w magazynie. Tylko kilka razy zostały pokazane w Chicago, największy ich wybór podczas prezentacji czasowej ,Art Deco — Poland” na przełomie 1999 i 2000 roku $^{38}$, a ostatnio w grudniu 2011 roku wyeksponowano kartki świąteczne autorstwa artystki. Zadbano o to, aby dwie litografie Marii Werten, należące do MPA prezentowane były — wraz z kolekcją 120 grafik ze zbiorów Muzeum Polskiego - w Krakowie, Wrocławiu i Chicago w 2009 oraz 2010 roku w ramach programu „Skarby kultury polskiej na emigracji” ${ }^{39}$. W katalogu towarzyszącym wystawie omówiono dość szczegółowo kolekcję Marii Werten ${ }^{40}$. Od grudnia 2008 roku, kiedy publikacja się ukazała, pojawiły się nowe informacje zreferowane na konferencji w Warszawie w 2009 roku $^{41}$, uzupełnione ponownie w niniejszym artykule.

Twórczość i życie Marii Werten jest tematem przygotowywanej od kilku lat w Chicago rozprawy doktorskiej, której publikację wraz z katalogiem dzieł artystki zaplanowano zgodnie z mottem Muzeum Polskiego w Ameryce: „Zachowujemy przeszłość dla przyszłości”. Obecnie tylko jedna praca Marii Werten, litografia Dziecko z lat 20. XX wieku, jest częścią ekspozycji stałej Muzeum Polskiego w Ameryce ${ }^{42}$.

Monika Nowak (Kraków)

38 J. Polański, Art Deco - Poland, [on-line]. [Dostęp: styczeń 2013]. Dostępny w WWW: http://www.artscope.net/VAREVIEWS/deco02_2000-1.shtml.

${ }^{39}$ M. Nowak, PMA Print Exhibition: Tour in Poland and United States, The Polish Museum of America Newsletter 2010 nr 4, s. 10-12.

${ }^{40}$ Taż, Madame Werten, [w:] Muzeum Polskie w Ameryce. Zbiory graficzne, [katalog wystawy], Muzeum Narodowe w Krakowie, Kraków 2007, s. 71-74.

${ }^{41}$ Taż, Zaginione i ocalone - grafiki z pawilonu polskiego oraz spuścizna Marii Werten w Chicago, [w:] Wystawa nowojorska 1939. Materiały z sesji naukowej Instytutu Sztuki PAN Warszawa, 23-24 listopada 2009 roku, red. J. M. Sosnowska, Warszawa 2012, s. 153-165.

${ }^{42}$ Od 4 listopada 2011 roku, dnia otwarcia — po gruntownym remoncie — nowej galerii sztuki międzywojennej w MPA, nazwanej Stephen and Elizabeth Ann Kusmierczak Art Gallery. 